\title{
Creeping compulsion to mediate, the Constitution and the Convention
}

\author{
RONÁN FEeHILY \\ University of Canterbury, Christchurch, New Zealand
}

\begin{abstract}
The court backlog in some European countries has inspired the introduction of compulsory mediation schemes to deal with various commercial claims. The article reviews the developing jurisprudence from various courts throughout Europe, to assess the seemingly relentless public policy move towards compulsory mediation and the implications that this has for commercial parties in dispute, lawyers involved in the process and the administration of justice in Europe. The potential that such an approach could amount to a violation of the rights guaranteed by Article 6(1) of the European Convention on Human Rights, as enshrined within the European Convention on Human Rights Act 2003, and Article 40.3 of the Irish Constitution is analysed. The article ultimately discusses the optimal approach for the courts and the legislature to follow to strike the appropriate balance between strong encouragement and coercive compulsion that would avoid offending constitutional and Convention rights and foster a mediation culture.
\end{abstract}

Keywords: compulsory; commercial; mediation; Article 6(1); Human Rights Convention; Article 40.3; Irish Constitution.

\section{Introduction}

$\mathrm{M}$ ediation is neither a new nor a novel concept in Ireland. Provision for mediation has been made in various pieces of Irish legislation over the past three decades. In the area of family law, solicitors are required to discuss with their clients the possibility of engaging in mediation as an alternative to litigation. ${ }^{1}$ Legislative provision for voluntary mediation has also been made to assist with a range of disputes between employers and employees, ${ }^{2}$ landlord and tenant disputes, ${ }^{3}$ personal injury disputes ${ }^{4}$ and in the area of social inclusion. ${ }^{5}$ Commercial Court judges possess the power to direct parties to consider

1 S 6, Judicial Separation and Family Law Reform Act 1989; s 6, Family Law (Divorce) Act 1996; s 20, Children Act 1997.

2 S 78, Employment Equality Act 1998; and s 24(1), Equal Status Act 2000. See also $<$ www.workplacerelations.ie/en/Workplace_Relations_Services/Mediation_Services>.

3 S 164, Residential Tenancies Act 2004.

4 S 15, Civil Liability and Courts Act 2004.

5 See, for example, s 19, Disability Act 2005; and s 55, Social Care Professionals Act 2005. 
mediation, ${ }^{6}$ and commercial contracts frequently provide that the parties must first attempt to mediate their disputes, prior to issuing court or arbitral proceedings. ${ }^{7}$

The most recent and most significant legislative initiative is the Mediation Act 2017, which provides a legal framework for the use of mediation in civil and commercial disputes. ${ }^{8}$ The Act covers a range of issues, including the requirement that a mediator and the parties sign an agreement to mediate, prior to the commencement of the mediation, dealing with practicalities, such as the manner in which the process will be conducted and the mediator's fee, ${ }^{9}$ and this agreement delays proceedings under the Statute of Limitations until 30 days after the successful conclusion or unsuccessful termination of the mediation. ${ }^{10}$ One of the most significant provisions in the Act is that a court may, on application by a party to proceedings or of its own motion where it considers it appropriate to do so, invite the disputing parties to consider mediation to resolve their dispute. In circumstances where the parties decide to engage in mediation, to facilitate the use of the process the court may adjourn the proceedings, make an order extending the time for compliance by a party with rules of court or with any other court order. ${ }^{11}$

While disputes are mediated in the 'shadow of the law', mediation is based on interests rather than rights and the consequent settlement agreement reached may be unrelated to the legal merits of the claim. ${ }^{12}$ The mediation process itself is not subject to fair trial requirements, and parties, particularly those that are not legally represented, will not necessarily be protected by the law or by the accountability afforded by a public judgment and an independent judiciary. Courts ensure public accountability for those whose wrongful acts may otherwise go unnoticed and provide protection for weaker parties who seek justice against those who exercise power over them. ${ }^{13}$ It is against this backdrop that Article 6(1) of the European Convention on Human Rights (ECHR) has a significant role in maintaining and upholding the important function of civil justice.

\section{European Convention on Human Rights Act}

Despite the absence of any requirement in the ECHR that it be incorporated into a domestic legal system, it does not itself have direct effect in Irish law in light of Ireland's

6 S 6(XIII), Rules of the Superior Courts (Commercial Proceedings) 2004.

7 While mediation is employed to resolve conflict in various fields, the focus of this article is on commercial mediation; the process that assists in the resolution of disputes between business parties. See E Carroll and K Mackie, International Mediation: The Art of Business Diplomacy (2nd edn, Kluwer Law 2006) 3-17. Mediation in this context may be defined as 'a flexible process conducted confidentially in which a neutral person actively assists parties in working towards a negotiated agreement of a dispute or difference, with the parties in ultimate control of the decision to settle and the terms of resolution', available at $<$ www.cedr.com/news/?item =CEDR-revises-definition-of-mediation $>$.

8 The Mediation Act 2017 was signed into law on 2 October 2017 and commended on 1 January 2018. The Act reflects many of the Irish Law Reform Commission's recommendations in the report it published in 2010 on alternative dispute resolution, discussed further below.

9 S 7, Mediation Act 2017.

10 Ibid s 18.

11 Ibid s 16. This is consistent with Order 56A of the Irish Superior Court Rules, discussed below. The relevant provisions of the Act are discussed under the appropriate parts below.

12 See Deborah R Hensler, 'Suppose It's not True: Challenging Mediation Ideology' (2002) 1 Journal of Dispute Resolution 81-99, 96.

13 See M Cappelletti, 'Alternative Dispute Resolution Processes within the Framework of the World Wide Access to Justice Movement' (1995) 56 Modern Law Review 287, 288. See also R A B Bush, 'Efficiency and Protection, or Empowerment and Recognition? The Mediator's Role and Ethical Standards in Mediation' (1989) 41 University of Florida Law Review 253, at 281-2. 
dualist approach to international law. ${ }^{14}$ Individuals cannot rely upon it as binding authority in an Irish court and Irish courts do not have the power to grant a declaration under it. ${ }^{15}$ The rights contained in the ECHR were enshrined in Irish law by the enactment of the European Convention on Human Rights Act 2003 (ECHR Act). ${ }^{16}$

As Ireland had a body of existing constitutionally protected rights, the ECHR rights comprised within the ECHR Act were to complement not supplement this, essentially involving the domestication ${ }^{17}$ rather than the incorporation of the ECHR into Irish law. The ECHR Act requires the courts to interpret legislation in line with the ECHR insofar as it is possible to do so, ${ }^{18}$ and requires certain public bodies to perform their functions in a manner compatible with the ECHR, unless precluded by law. ${ }^{19}$

In Doran $v$ Ireland ${ }^{20}$ the ECtHR pointed out that Article 13 of the ECHR ${ }^{21}$ guarantees the availability of a remedy at national level to enforce the substance of Article 6 rights and freedoms in whatever form they may happen to be secured in the domestic legal order. The remedy, according to the court, must be effective in both law and practice. The ECHR Act provides that courts may make a declaration of incompatibility regarding a breach of a Convention right. Unlike a declaration that a law is repugnant to the Constitution, ${ }^{22}$ a declaration of incompatibility has no effect on the continued validity and enforcement of that law, unless and until it is amended by the Irish legislature. ${ }^{23}$

In circumstances where counsel have argued that their client's rights under Article 6 ECHR have been violated, Irish judges have been vigilant in reminding them that the rights reflected in Article 6 ECHR are part of Irish law by virtue of the ECHR Act, and

14 See Suzanne Kingston, 'Impact of EU Human Rights Law and ECHR Law in Irish Courts' in Suzanne Egan, Liam Thornton and Judy Walsh, Ireland and the European Convention on Human Rights: 60 Years and Beyond (Bloomsbury Professional Dublin 2014) 111-12.

15 Article 15.2.1 of the Irish Constitution provides: 'The sole and exclusive power of making laws for the State is hereby vested in the Oireachtas [Irish legislature]: no other legislative authority has power to make laws for the State'; while Article 29.6 provides: 'No international agreement shall be part of the domestic law of the State save as may be determined by the Oireachtas.' For a discussion on the need for incorporating legislation, see Fiona de Londras and Cliona Kelly, European Convention on Human Rights Act, Operation, Impact and Analysis (Thomson Round Hall 2010) 5-9.

16 While the ECHR had persuasive effect in Irish law prior to the commencement of ECHR Act, the obligations in the Act do not apply where the actions complained of took place prior to the Act coming into effect. See Dublin City Counsel v Fennell [2005] 1 IR 604. For a discussion on the temporal scope of the ECHR Act, see de Londras and Kelly (n 15) 45-7.

17 Fiona de Londras, 'Neither Herald nor Fanfare: The Limited Impact of the ECHR Act 2003 on Rights Infrastructure in Ireland' in Egan et al (n 14) 40.

18 S 2, ECHR Act 2003.

19 Ibid s 3.

20 App no 50389/99.

21 Article 13 of the ECHR provides: 'Everyone whose rights and freedoms as set forth in this Convention are violated shall have an effective remedy before a national authority notwithstanding that the violation has been committed by persons acting in an official capacity.'

22 See Donncha O'Connell, 'The ECHR Act 2003: A Critical Perspective' in Ursula Kilkelly, ECHR and Irish Law (Jordans 2004) 3. See also Gerard Hogan, Incorporation of the ECHR: Some Issues of Methodology and Process' in ibid 21-8, for a discussion on the differences between the declarations of unconstitutionality and incompatibility.

23 S 5, ECHR Act 2003. For a discussion on the delay in enacting legislation where declarations of incompatibility have been granted, see Suzanne Kingston, 'Two-speed Rights Protection? Comparing the Impact of EU Human Rights Law and ECHR Law in Irish Courts' in Egan et al (n 14) 113. For an interesting discussion on the relationship of conflict and confluence between the Irish Constitution and the ECHR from the perspective of a High Court judge (now a judge of the Court of Appeal) writing extra-judicially, see Gerard Hogan, 'The Constitution and the Convention: Happily Married or a Loveless Co-existence?' in Egan et al (n 14) 73-86. 
that the latter is the source of such rights. For example, in Foy $v$ An tArd-Chlaraitheoir, ${ }^{24}$ McKechnie J described the position of the Convention within Irish law as follows:

It is a misleading metaphor to say that the Convention was incorporated into domestic law. It was not. The rights contained in the Convention are now part of Irish law. They are so by reason of the Act of 2003. That is their source. Not the Convention. So it is only correct to say, as understood in this way, that the Convention forms part of our law.

Similarly, Denham CJ in MD (a minor) v Ireland ${ }^{25}$ stated:

The claim, as pleaded, is simply that s. 3 is 'in breach of' the Convention. That formulation is not acceptable. It treats the Convention as if it had direct effect and presumes that the Court has the power to grant a declaration that a section is in breach of the Convention. It is clear from the judgments of this Court in McD v L [2010] 2 IR 199 that the European Convention on Human Rights Act 2003 did not give direct effect in Irish law to the European Convention on Human Rights. As Murray C.J. stated at page 248, 'The Convention does not of itself provide a remedy at national level for victims whose rights have been breached by reference to the provisions of the Convention'.

As Denham CJ illustrated, it is well established by the Irish Supreme Court that the ECHR may only be pleaded by reference to its limited incorporation through the ECHR Act. One must identify the precise statutory provision or rule of law that is being challenged, and the contentions regarding its compliance or otherwise with the ECHR must be based strictly on the interpretative obligation upon the courts, the duty on any organ of the state to act in a ECHR compliant manner, and/or the duty on the courts to grant a declaration of incompatibility regarding a precise statutory provision or rule of law. ${ }^{26}$ Jurisprudential evidence reveals that the Irish courts have largely engaged with the ECHR within the limits of the Irish constitutional framework. ${ }^{27}$ The remedies available where a breach of the ECHR Act occurs have been limited, and this is largely due to the failure of the Irish legislature to bring Irish law into compliance with the ECHR and this, it has been suggested, has inhibited the courts' approach. ${ }^{28}$

\section{Costs sanctions and the compulsion to mediate}

In circumstances where there is a significant risk of onerous costs orders being imposed on recalcitrant parties, it is likely that there will be a significant rise in the number of disputes being mediated. ${ }^{29}$ If the Irish courts are to follow the same path as other jurisdictions, it is likely that commercial mediation will only become a prominent form of dispute resolution when heavy costs penalties are deployed by the courts. A judge of the

24 [2007] IEHC 470, para 93.

25 [2012] IESC 10, para 59.

26 Suzanne Kingston and Liam Thornton, A Report on the Application of the European Convention on Human Rights Act 2003 and the European Charter of Fundamental Rights: Evaluation and Review (Law Society of Ireland and Dublin Solicitors Bar Association 2015) 35. For a detailed discussion on the limitations of the ECHR Act in terms of the court's interpretive obligations, the obligations of state organs under the Act and the obligation of the courts to award a declaration of incompatibility where there is no alternative remedy to a breach of ECHR rights, see de Londras and Kelly (n 15) chs 4, 5 and 7 respectively.

27 Kingston and Thornton (n 26) 151.

28 Ibid 154.

29 For a discussion on the experience in England after the changes to the Civil Procedure Rules in light of the Woolf reforms discussed further below, see Antony Dutton and Daniel Perera, 'Mediation as a Costcontainment Device in the English Courts: Litigation Becomes the "Last Resort" in Dispute Resolution', (Mediation Committee Newsletter, IBA Legal Practice Division September 2006) 32. 
Irish Commercial Court suggested over a decade ago that there may be costs implications for parties in certain circumstances where those parties refuse to even consider mediation, despite the absence of legislation at that time facilitating this. ${ }^{30}$ Costs sanctions are now provided for in the Mediation Act 2017, under which a court may, where it considers it just to do so, take into account any unreasonable refusal or failure by a party to consider using mediation, or to attend mediation, when awarding costs in the proceedings. ${ }^{31}$

The provision for a costs sanction in the Mediation Act 2017 for an unreasonable refusal to mediate is consistent with the pre-existing position under the Rules of the Superior Courts (RSC) following amendments to them in 2010. In an effort to encourage the use of mediation and other alternative dispute resolution (ADR) processes other than arbitration as part of the courts process, statutory instrument 502 of 2010 (SI 502) introduced a new order 56A to the RSC. Under this rule, the court may, either on application of any of the parties to proceedings or of its own motion, order that proceedings or any issue therein be adjourned and invite the parties to use mediation or, where the parties consent, refer the proceedings or issue to mediation. A new rule $1 \mathrm{~B}$ was added to order 99 RSC that provides for the court, where an order has been made, to have regard to the refusal or failure without good reason of any party to participate in mediation when awarding costs. ${ }^{32}$ These rules also give further effect to the European Communities (Mediation) Regulations $2011^{33}$ that support the framework for mediation of disputes within the European Union (EU) that have a cross-border element.

In Irish School of Yoga Ltd v Henkel Murphy, ${ }^{34}$ a dispute relating to the termination of a franchise agreement, the High Court granted an order inviting the parties to use ADR to attempt to resolve their dispute under order 56A. Justice Laffoy remarked that:

... prudence dictates that the parties should process the remainder of their differences through an ADR process. What is at stake in these proceedings is totally disproportionate to the costs which will be incurred in pursuing a High Court action ... Accordingly, there will be an order under Order 56A inviting the parties to use an ADR process. ${ }^{35}$

30 The Irish Commercial Court is a division of the High Court. See Mr Justice Peter Kelly in Michael Tyrrell and Patrick Walshe, 'New Mediation Provisions Enacted' (Mediation Committee Newsletter, IBA Legal Practice Division April 2005) 21. Mr Justice Kelly subsequently remarked that he had never had to make a mediationrelated costs order nor had a case where someone behaved unreasonably in relation to a request to mediate. See Mr Justice Peter Kelly, 'Speech delivered at the Mediation Works Symposium' (27 May 2008).

31 S 21, Mediation Act 2017.

32 The rule came into force on 16 November 2010 and is similar to the procedure in the Commercial Court mentioned above. As discussed below, England has a developed jurisprudence with regard to costs sanctions for an unreasonable refusal to mediate. In addition to SI 502/2010 introducing a new order 56A to the Rules of the Superior Courts, the likelihood of Irish courts following English decisions on costs sanctions is also supported by the broad provisions of order 99, Rules of the Superior Courts, and the advent of s 21 of the Mediation Act 2017. See also J Fox, 'Order 56A and the Cost Implications of Refusal to Engage in ADR' (Bar Review April 2007) 22-5.

33 This transposed Directive 2008/52/EC of the European Parliament and the Council of 21 May 2008 on certain aspects of mediation in civil and commercial matters (the Mediation Directive) into Irish law, available at <http://eur-lex.europa.eu/legal-content/EN/TXT/?uri=CELEX:32008L0052>. See Seán Barton and Heather Mahon, 'Ireland' in Michael Madden (ed), Litigation and Dispute Resolution (2nd edn, Global Legal Group) $138<$ http://docplayer.net/37739689-Litigation-dispute-resolution.html>.

34 [2012] IEHC 218.

35 [2012] IEHC 218. The provision for a costs sanction for unreasonably refusing to mediate a dispute to support this rule has not to date been employed by the courts. 
The case illustrates the willingness of the courts to use the rule to encourage the use of mediation in appropriate circumstances.

A recurring theme in jurisdictions where commercial mediation is well established, and an issue that Irish practitioners and the judiciary must remain mindful of, is the concern expressed that the more vigilant the judiciary becomes in encouraging mediation through the use of costs sanctions, the more it appears that mediation is becoming compulsory. In determining costs, courts in jurisdictions where costs penalties have been applied have had to decide when reviewing the parties' behaviour, whether they are willing to look inside the process and consequently infringe upon mediation confidentiality. 36 The concern is that the further that sanctions are likely to extend, the greater the likelihood that mediation confidentiality will be eroded. In light of the approach adopted in the Mediation Act 2017,37 which provides for comprehensive mediation confidentiality subject to limited exceptions, the Irish legislature ${ }^{38}$ has followed the English position of protecting mediation communications, and it is to be hoped that the confidentiality provisions in the Act will be applied strictly by the courts. ${ }^{39}$

Compulsory forms of mediation, if employed in Ireland are likely to run into allegations that they violate the rights guaranteed by Article 6 of the ECHR, as reflected in the ECHR Act and Article $40.3^{40}$ of the Irish Constitution. Experience of mediation when recommended in the Commercial Court would seem to indicate, similar to the experience of the judiciary in the UK, that voluntary mediation is preferable to compulsory mediation as it is more likely to lead to a successful outcome. ${ }^{41}$ The Irish courts have the benefit of, and can glean guidance from, English, European Court of

36 See Carleton (Earl of Malmesbury) v Strutt \& Parker [2008] EWHC 424 (QB); [2008] 5 Costs LR 736, where both parties unusually waived confidentiality and the successful claimant's costs award was reduced due to his unreasonable conduct in the mediation process. See also In Kay-El (Hong Kong) Ltd v Musgrave Ltd [2005] IEHC 418. See Fox (n 32) 25. Article 7 of the Mediation Directive requires member states to ensure that mediators and others involved in a mediation process, in the absence of agreement, are not compelled to give evidence in civil, commercial or arbitration proceedings regarding information arising out of the mediation process except where necessary for overriding reasons of public policy or where necessary to enforce a mediated settlement agreement.

37 S 10, Mediation Act 2017.

38 While accepting that objectively verifiable actions such as complete refusal to consider mediation could attract a costs sanction, the Irish Law Reform Commission advised against imposing a good faith requirement on mediating parties as this would risk undermining key principles including the impartiality of the mediator and the confidentiality of the process, and this approach is now reflected in s 10 of the Mediation Act 2017. The commission approved of the approach in Halsey, discussed below, that the court determines whether to impose costs sanctions without having to explore the subjective intentions of the parties during mediation. See Law Reform Commission, Alternative Dispute Resolution Report: Mediation and Conciliation (LRC 98-2010) 90$2<$ www.lawreform.ie/_fileupload/Reports/r98ADR.pdf>.

39 In Farm Assist Ltd (in Liquidation) v Secretary of State for the Environment, Food and Rural Affairs [2009] BLR 399, Ramsay J clarified that, in England, a communication remains privileged even where the client shares it with the mediator on a confidential basis. Consequently, the client will be able to restrain the mediator from making any unauthorised use of the information. For a discussion of the case see, A K C Koo, 'Confidentiality of Mediation Communications' (2011) Civil Justice Quarterly 192, 200. See also 'Case Comment: Mediation' (July/August 2009) Construction Newsletter 7. For a discussion on the need and the rationale for the introduction of a distinct mediation privilege in England, in part to bring it into line with European jurisprudence, see Koo 'Confidentiality' 192-203.

40 Article 40.3 subparts 1 and 2 of the Irish Constitution provide: ' 1 The State guarantees in its laws to respect, and, as far as practicable, by its laws to defend and vindicate the personal rights of the citizen. 2 The State shall, in particular, by its laws protect as best it may from unjust attack and, in the case of injustice done, vindicate the life, person, good name, and property rights of every citizen.'

41 Mr Justice P Kelly, 'Alternative Dispute Resolution and the Commercial Court' [2010] Arbitration and ADR Review 92-7, 93. 
Justice (ECJ) and European Court of Human Rights (ECtHR) jurisprudence when dealing with these issues.

Dyson LJ, in delivering the Halsey v Milton Keynes NHS Trust judgment, remarked that 'to oblige truly unwilling parties to refer their disputes to mediation would be to impose an unacceptable obstruction on their right of access to the courts . . . and, therefore, a violation of article $6^{42}$. He subsequently regretted making the remarks on the issue of compulsion. He conceded that in and of itself compulsory mediation does not breach article 6', based on the judgment of the ECJ in Rosalba Alassini v Telecom Italia SpA. ${ }^{43}$ The ECJ in Alassini ${ }^{44}$ decided that a provision in Italian law which required parties to submit to mediation, failing which they forfeited their right to bring proceedings before the courts, was not in contravention of Article 6.45

The court in Alassini found that, provided compulsory mediation schemes are in the general interest and proportionate, the principle of effective judicial protection does not preclude them. A critical element in the case was the judicial presumption, supported by observations provided by the German government, that a voluntary mediation scheme would not be as effective. Unfortunately, the background rationale for this position is not included in the judgment. Advocate General Kokott concluded that:

[the] mandatory dispute resolution procedure without which judicial proceedings may not be brought does not constitute a disproportionate infringement upon the right to effective judicial protection ... Provisions such as these constitute a minor infringement upon the right to enforcement by the courts that is outweighed by the opportunity to end the dispute quickly and inexpensively. ${ }^{46}$

The scheme in the case was free of charge to the parties. It remains to be seen what the outcome will be if a case in the future comes before the court to be decided where a similar scheme involves a significant cost, as the higher the cost of mediation, the stronger the argument that it constitutes a greater hurdle as regards access to justice. With regard to the criticisms of Dyson LJ's judgment in Halsey mentioned above, Alassini does not confirm the Court of Appeal's view that a compulsory scheme would interfere with the right to trial, but 'at most it merely imposes a short delay'. ${ }^{47}$

Other leading English jurists, such as Lightman J, Lord Phillips CJ, Lord Clarke MR and Sir Anthony Clarke MR, have also commented that an order for mediation does not interfere with the right to trial, as it does not propose mediation in lieu of a trial, but merely imposes a delay. Lord Phillips, for example, a former head of the judiciary in England and Wales and founding president of the UK's Supreme Court, who referred specifically to Dyson LJ's judgment in Halsey ${ }^{48}$ and proceeded to say that: 'Parties should

42 Halsey v Milton Keynes NHS Trust [2004] EWCA Civ 576; [2004] 1 WLR 3002; [2004] 4 All ER 920, 9.

43 See Lord Dyson, 'A Word on Halsey v Milton Keynes' [2011] 77(3) Arbitration 337, 337, 339, keynote speech, Third Annual Mediation Symposium of the Chartered Institute of Arbitrators (London, October 2010). See also Lord Dyson MR, 'Halsey 10 Years On - The Decision Revisited' (keynote speech, Belfast Mediation Conference May 2014) 6, 10.

44 Rosalba Alassini v Telecom Italia SpA (C-317-320/08) [2010] 3 CMLR 17.

45 See Gary Meggitt, 'PGF II SAv OMFS Co and Compulsory Mediation' (2014) 33(3) Civil Justice Quarterly 335-348, 335 and 348.

46 Rosalba Alassini v Telecom Italia SpA (C-317-320/08) [2010] 3 CMLR 17, para 57. For a detailed discussion of this case, see Jim Davies and Erika Szyszczak, 'Case Comment, ADR: Effective Protection of Consumer Rights?’ (2010) 35(5) European Law Review 695-707.

47 Lightman J, 'Breaking Down the Barriers' (The Times Online 31 July 2007) <http://business.timesonline.co.uk/tol/business/law/article2166092>.

48 [2004] EWCA (Civ) 576. 
be given strong encouragement to attempt mediation before resorting to litigation. And if they commence litigation, there should be built into the process a stage at which the court can require them to attempt mediation. ${ }^{49}$ Others support this view by pointing to the fact that compulsory mediation occurs in other jurisdictions, such as Germany, Italy and Greece, with no successful Article 6 challenges. ${ }^{50}$

However, Jackson LJ rejected compulsory mediation in his Review of Civil Litigation Costs Final Report, 51 although, consistent with the rationale in Halsey, he supported sanctions against those who unreasonably refused to mediate. ${ }^{52}$ Despite such judicial clarification, some contend that the courts in England do in fact compel mediation surreptitiously, through the use of what is termed implied compulsory mediation. The contention is that while officially mediation is not compulsory, in practice implied compulsory mediation forms part of the civil justice system, through a process where judges, supported by the Civil Procedure Rules (CPR), are making it clear to parties that they expect that they will engage in mediation, and parties, mindful of the potential adverse cost consequences, feel compelled to engage in the process. This issue has been exacerbated, it seems, by austerity over a number of years and the consequent pressure on court resources. 53

Dyson LJ's support for mediation and the use of costs sanctions to support it is not unqualified. He has remarked that 'the court should not exercise that power if it is satisfied that the parties are truly unwilling to embark upon a mediation'. ${ }^{54} \mathrm{He}$ argued that compulsory mediation could constitute a denial of access to justice in some circumstances, for example, if coupled with high mediation costs, and that it is not the role of a court of law to force compromise upon disputants who do not want it. 55 However, in light of the seemingly low cost of mediation compared with the high cost of going to trial, the costs issue is unlikely to arise. With regard to the second contention, it risks violating the cardinal principle of equality before the law to treat litigants unequally on the basis of their willingness to mediate and one should not confuse a degree of compulsion to enter into a process from which settlement may result, a process that parties may exit at any time, with the settlement itself that will be arrived at only

49 See speech by Lord Phillips of Worth Matravers, Lord Chief Justice of England and Wales, 'Alternative Dispute Resolution: An English Viewpoint' (India 29 March 2008) <www.civilmediation.org/downloadsget?id=119>.

50 See Lightman J, 'Mediation: An Approximation to Justice' (speech given at S J Berwin, 28 June 2007) <www.judiciary.gov.uk/Resources/JCO/Documents/Speeches/berwins_mediation.pdf>; Matravers (n 49); Sir Anthony Clarke MR, 'The Future of Civil Mediation' (8 May 2008) <www.civilmediation.org/downloadsget?id=128>; Lord Clarke MR, 'Mediation - An Integral Part of our Litigation Culture' (Littleton Chambers Annual Mediation Meeting, Gray's Inn, 8 June 2009). See also Kenneth J Ryan, 'Promoting ADR through the Imposition of Costs Sanctions: Is it the right Approach?’ (International Bar Notes February 2013) 13-19, 14.

51 See also Irish Law Reform Commission, Consultation Paper on Alternative Dispute Resolution (LRC CP 50-2008) 74.

52 See Jackson LJ, 'Review of Civil Litigation Costs Final Report', 14 January 2010, xxiii <https://www.judiciary.gov.uk/wp-content/uploads/JCO/Documents/Reports/jackson-final-report140110.pdf>.

53 See Masood Ahmed, 'Implied Compulsory Mediation' (2012) 31 Civil Justice Quarterly 151-75, specifically 164-70. See also Sue Prince, 'Mandatory Mediation: the Ontario Experience' [2007] Civil Justice Quarterly 79$95,93$.

54 See Dyson, 'A Word on Halsey' (n 43); and 'Halsey 10 Years On' (n 43).

55 See Dyson, 'A Word on Halsey' (n 43); and 'Halsey 10 Years On' (n 43) 
when it is reduced to writing and signed by both parties, and in a commercial context drafted and reviewed by the party's respective legal teams. ${ }^{56}$

In the USA, compulsory mediation schemes have been introduced in a number of states with federal district courts empowered to require parties to mediate disputes under a power granted by the Alternative Dispute Resolution Act 1998. ${ }^{57}$ Signatories to the ECHR, such as Belgium and Greece, have adopted compulsory mediation schemes without any successful Article 6 challenges. Similarly, in Germany, federal states can introduce legislation to require litigants to either engage in court-based or court-approved mediation prior to litigation commencing. ${ }^{58}$ The European Commission has stated that the EU actively promotes and encourages the use of mediation to assist dispute resolution and avoid the worry, time and cost associated with litigation. ${ }^{59}$ This is reflected in Article 3(2) of the Mediation Directive that provides that the encouragement it offers to mediation is made 'without prejudice to national legislation making the use of mediation compulsory ... provided that such legislation does not interfere with the right of access to justice'. Such experiences appear to indicate that schemes of compulsory mediation do not in and of themselves give rise to a violation of Article 6, 60 provided mediation is presented as a condition precedent to litigation or arbitration and not the only means of resolution. ${ }^{61}$

\section{Commercial mediation, the Constitution and the Convention}

In Golder $v$ UK, ${ }^{62}$ the ECtHR remarked that 'one can scarcely conceive of the rule of law without there being a possibility of having access to the courts'. 63 The Irish Supreme Court in Tuoby $v$ Courtney ${ }^{64}$ acknowledged the distinct rights to litigate and to have access to the courts. While access to the courts is an important constitutional and Convention right, formal complex procedural rules have resulted in costly legal advice. ${ }^{65}$ Dissatisfaction with the administration of justice has been a public concern for some time, ${ }^{66}$ and in this context mediation has a crucial role to play in providing wider access

56 See A K C Koo 'Ten Years after Halsey' [2015] 34(1) Civil Justice Quarterly 77-95, 79-80.

57 S 652 (28 USC).

58 Katja Alexander et al, 'Mediation in Germany: The Long and Winding Road' in Katja Alexander (ed), Global Trends in Mediation (2nd edn, Kluwer Law 2006) 233. The experience in Ontario suggests that an enhanced voluntary mediation scheme is a better solution and less financially burdensome on the state than a compulsory one. See Ministry of Justice, 'Solving Disputes in the County Courts: Creating a Simpler, Quicker and More Proportionate System: A Consultation on Reforming Civil Justice in England and Wales - The Government Response' (CM8274 February 2012) 172.

$59<$ https://e-justice.europa.eu/content_eu_overview_on_mediation-63-en.do>

60 Courts in the USA have developed a tradition of ordering mediation in the face of resistance from the parties. In Re Atlantic Pipe Corporation [2002] 304 F3d 135, the Court of Appeals for the First Circuit said that a Federal Trial Court has the inherent authority to order compulsory mediation where appropriate. It remarked that, in some cases, a court may be warranted in believing that compulsory mediation could yield significant benefits, even if one or more parties objects, believing that while the parties may fail to reach agreement, the benefit of settlement can be worth the risk.

61 See, for example, ibid.

62 (1975) 1 EHRR 524.

63 Golder v UK (1975) 1 EHRR 524, para 34.

64 [1994] 3 IR 1, ILRM 503. See also G W Hogan, G F Whyte and J M Kelly: The Irish Constitution (4th edn, Tottel 2003) 1446.

65 Rita Drummond, 'Court-annexed Mediation in England: Foundations for an Independent and Enduring Partnership' (November 2007) <http://ssrn.com/abstract=962122>.

66 Roscoe Pound, 'The Causes of Popular Dissatisfaction with the Administration of Justice' (1906) 39 Reports of the American Bar Association, Part 1, 395. 
to justice and, as reflected in the Mediation Act 2017, the courts have a fundamental role in integrating mediation into the civil justice system by encouraging parties to consider mediation in appropriate cases. ${ }^{67}$

Article 6 is the most frequently invoked and most robust ECHR article, stemming from the gravity of the right comprised in it. ${ }^{68}$ The prominent position given to the right to a fair trial is symbolic of its value in upholding a democratic society. ${ }^{69}$ Length of proceedings in civil cases represents the most frequently invoked violation of Article 6.70 Mediation has emerged as a possible partial solution to what many view as an insoluble problem. ${ }^{71}$

Article 6(1) of the ECHR provides:

In the determination of his civil rights and obligations or of any criminal charge against him, everyone is entitled to a fair and public hearing within a reasonable time by an independent and impartial tribunal established by law. Judgment shall be pronounced publicly ...

Consistent with its aim and purpose, Article 6(1) has been interpreted broadly by the ECtHR. ${ }^{72}$ This has resulted in the creation of new guarantees that are not specifically mentioned in the article and are considered as natural corollaries of the written guarantees of Article 6, such as the right of access to justice which has developed into one of the fundamental guarantees of Article $6 .{ }^{73}$ The ECtHR believed that any interpretation of Article 6 that did not view Article 6(1) as concerning both the conduct of proceedings, and the actual right to institute them in the first place would contradict a universally recognised principle of law and would allow the state to close its courts without infringing the ECHR, resulting in the right of access to justice developing into one of the fundamental guarantees of Article 6. ${ }^{74}$ In Airey $v$ Ireland, ${ }^{75}$ the ECtHR held that the ECHR is intended to guarantee rights that are practical and effective rather than rights that are theoretical or illusory.

Both the structure and content of ECHR Article 6(1) and the guarantees under the Irish Constitution are quite similar. As noted above, Article 6(1) provides for a basic entitlement to fair procedures in civil and criminal matters. The equivalent constitutional provisions are reflected in a number of articles. Article $38^{76}$ elucidates guarantees

67 See also Irish Law Reform Commission (n 51) 331.

68 D J Harris, M O Boyle and C Warbrick, Law of the European Convention on Human Rights (1st edn, Butterworths 1995) 164; and De Cubber v Belgium [1984] ECHR 14. It is also the article most frequently found to have been violated, see Helen Fenwick and Gavin Phillipson, Text, Cases and Materials on Public Law and Human Rights (3rd edn, Routledge 2011) 311.

69 Harris et al (n 68); De Cubber v Belgium [1984] ECHR 14.

70 See, for example, Christof Rozakis, 'The Right to a Fair Trial in Civil Cases' [2004] Judicial Studies Institute Journal 97. See also Council of Europe/European Court of Human Rights, Guide on Article 6 of the European Convention on Human Rights, Right to a Fair Trial (Civil Limb) (2013) 50-4, available at <www.echr.coe.int/Documents/Guide_Art_6_ENG.pdf>.

71 Warren Winkler CJ (Ontario), ‘Access to Justice, Mediation: Panacea of Pariah?' (2007) $<$ www.ontariocourts.on.ca/coa/en/ps/index.htm>.

72 Delcourt v Belgium (1970) 1 EHRR 355.

73 See Golder $v$ UK (1975) 1 EHRR 524, see para 28 and subsequent paras. See also Christof Rozakis, 'The Right to a Fair Trial in Civil Cases' [2004] 2 Judicial Studies Institute Journal 96-106, 98.

74 Rozakis (n 73) 98.

75 (1979) 2 EHRR 305.

76 Article 38.1 of the Irish Constitution provides: No person shall be tried on any criminal charge save in due course of law.' 
pertaining to a trial in due course of law on criminal matters. Article $34^{77}$ provides a general principle of fair procedures that apply to the administration of justice in court, and, in the case of other decision-making bodies, this principle is comprised within the unenumerated rights provisions of Article 40.3. ${ }^{78}$ There are clear equivalents between the two instruments. For example, Article 6(1) provides a guarantee of a fair trial by an impartial tribunal, while Article 35.2 of the Constitution provides that judges shall be independent in the exercise of their judicial functions and subject only to the Constitution and the law. The guarantee of fair procedures in civil matters is not quite as explicit in the Constitution as in the ECHR, but they are elucidated in constitutional jurisprudence. ${ }^{79}$

While there is a significant degree of similarity between the guarantees comprised in Article 6 of the ECHR, now enshrined in the ECHR Act, and Articles 34, 38 and 40.3 of the Constitution, it appears that there are areas that will remain purely the reserve of the Irish constitutional guarantees and that the level of scrutiny required by the Constitution is likely to be greater than that under the ECHR. Consequently, the constitutional provisions are likely to be the definitive port of call for most challenges to civil procedures albeit that the argument will be influenced by the jurisprudence under the ECHR. As noted above, this approach would seem to be consistent with the approach envisaged by the legislature in the ECHR Act, as it requires the courts to interpret legislation in line with the ECHR insofar as it is possible to do so. ${ }^{80}$ However, the ECHR Act may be the only instrument providing the possibility of a remedy resulting in a divergence from constitutional principles of Irish law. An example of such divergence, prior to the introduction of the ECHR Act, where the ECHR provided a remedy for which there was no immediate Irish equivalent is in the area of delay in civil proceedings. ${ }^{81}$ It has been suggested that the Irish courts are more likely to declare constitutional rights rather than find breaches of the ECHR Act in situations where, if the ECHR had never been incorporated as part of Irish law, it is questionable as to whether the right would have been identified at all. ${ }^{82}$

However, albeit that they are not strictly bound by it, Irish courts must take account of ECtHR jurisprudence, ${ }^{83}$ and experience suggests that Irish courts are extremely reluctant to develop an autonomous meaning of ECHR rights as protected by the ECHR Act that depart from ECtHR jurisprudence. ${ }^{84}$ This approach by the Irish courts

77 Article 34.1 of the Irish Constitution provides: 'Justice shall be administered in courts established by law by judges appointed in the manner provided by this Constitution, and, save in such special and limited cases as may be prescribed by law, shall be administered in public.'

78 Article 40.3 subparts 1 and 2 of the Irish Constitution (n 40).

79 In Re Haughey [1971] IR 217 (HC); State (Healy) v Donoghue [1976] IR 325 (HC \& SC); Kiely v the Minister for Social Welfare [1977] IR 267 (HC \& SC); and O’Brien v Bord Na Mona [1983] IR (HC \&SC). With regard to the potential issues under Article 6 that have already arisen under the Constitution as applies to the enforcement of the independence of the judicial function, it has been suggested that the Constitution as interpreted requires a more robust approach and more exacting standards than Article 6 of the ECHR. See, for example, Maher v Attorney General [1973] IR 140 (SC); Deaton v Attorney General [1963] IR 170 (SC); and Curtis v Attorney General [1985] IR 458 (HC). For a more detailed discussion of this issue, see Donal O'Donnell, 'A Comparison of Article 6 of European Convention on Human Rights and the Due Process Requirements of the Constitution of Ireland' [2004] Judicial Studies Institute Journal 37-67, 41-2, 44.

80 S 2, ECHR Act 2003.

81 See O’Donnell (n 79) 56-7.

82 See James MacGuill, ‘The Impact of Recent ECHR Decisions on the Constitution’ [2007] 2 Judicial Studies Institute Journal 50-75, 52. For a discussion of common law, the ECHR law and comparative constitutional law, see generally R Clayton and H Tomlinson, The Law of Human Rights (Oxford University Press 2009).

83 S 4, ECHR Act 2003. See also de Londras (n 17) 46.

84 See, for example, $M c D v L$ [2009] IESC 81. See also de Londras (n 17) 45-8. 
makes discussion of ECtHR jurisprudence particularly salient in assessing the likely approach of the Irish courts in dealing with constitutional and ECHR Act rights of access to the courts.

\section{BREACHES ARISING FROM THE PRESSURE TO MEDIATE}

There are potentially at least three situations where an applicant may seek to claim that their Article 6(1) rights have been infringed in the context of the pressure to undertake mediation. ${ }^{85}$ The first is where a party reached a mediated settlement agreement and consequently cannot pursue an action in court. As the agreement that results from a successful mediation is likely to reflect the interests of the parties rather than their legal rights, it is less likely to reflect the legal merits involved in a potential claim, and parties may settle for less than they would achieve through a negotiated settlement and will often discharge their own costs. ${ }^{86}$ However, it is not usually possible for the courts to review the settlement agreements as they are binding contracts. ${ }^{87}$

The second possible challenge arises where funds are expended on an unsuccessful mediation that could have been employed as litigation costs. However, in the context of commercial mediation, experience suggests that mediating disputes costs significantly less than litigation, and this challenge would have greater relevance to low-value claims. ${ }^{88}$

The third possible basis for a challenge could occur where a party is successful in their court action, but due to their unreasonable refusal to mediate the dispute the party receives an adverse costs award and consequently contends that this constitutes a denial of their right of access to court, i.e. that their right of access to court is 'theoretical and illusory'. This claim could be defeated if it can be shown that the party waived their right by going to mediation, provided the type of dispute falls within the ECtHR autonomous definition of 'civil rights and obligations' and is consequently covered by Article 6(1). ${ }^{89}$ While there is some doubt whether some of the procedural rights encompassed in Article 6(1) are capable of waiver, ${ }^{90}$ the right of access to court is not absolute, and the ECtHR has confirmed on numerous occasions that Article 6 does not prevent a party from waiving their right to a fair trial of their own free will, either expressly or tacitly. ${ }^{91}$

85 See Rhona Smith, Textbook on International Human Rights (5th edn, Oxford University Press 2012) 106-7. See also Philip Leach, Taking a Case to the European Court of Human Rights (3rd edn, Oxford University Press 2012) 26-76. See also Shirley Shipman, 'Waiver: Canute against the Tide?' (2013)32(4) Civil Justice Quarterly $475-7$.

86 For example, see Hazel Genn, 'Central London County Court Pilot Mediation Scheme: Evaluation Report' (LCD Research Series 5/98), 70, 71, 88-89, 97. See also Shipman (n 85) 475.

87 Mediated settlements of commercial disputes are binding contracts when reduced to writing and signed by the parties and are consequently enforceable through the courts. Article 6 of the Mediation Directive provides that EU member states must ensure that the content of a written agreement arising from a mediation should be made enforceable at the request of the parties. The court would only look to set aside the mediated settlement agreement if there was, for example, evidence of duress or coercion. See R Feehily, 'The Legal Status and Enforceability of Mediated Settlement Agreements' [2013] 12(1) Hibernian Law Journal 1-26.

88 In light of the confidential nature of the process, it is impossible to glean objective independent empirical evidence on this point. See generally Grania Langdon-Down, 'Commercial Mediation: Resolution Revolution?' (Law Society Gazette, England and Wales, 30 September 2013) $<$ www.lawgazette.co.uk/law/commercial-mediation-resolution-revolution/5037884.fullarticle>.

89 See Stankov v Bulgaria (2009) 49 EHRR 7. See Shipman (n 85) 476.

90 The ability to waive one's right to an impartial tribunal would be an example. See Pfeifer v Planklv Austria [1992] 14 EHHR 692; Ozerov v Russia (64962/01) Judgment May 18, 2010. See also Shipman (n 85) 476.

91 See Richard Stone, Textbook on Civil Liberties and Human Rights (10th edn, Oxford University Press 2013) 184; see also Sejdovic v Italy (56581/00) Judgment 1 March 2006. See also Shipman (n 85) 476. 


\section{The CONDITIONS to EFFeCtively WAive ARTiCle 6(1) RIGHTS}

As discussed below, arbitration clauses provide an example of an effective waiver of the right of access to court that does not conflict with the ECHR. ${ }^{2}$ In determining whether a right under Article 6(1) has been effectively waived, the ECtHR has reviewed whether four criteria have been satisfied. ${ }^{93}$

First, the waiver must be unequivocal, ${ }^{94}$ but this can be implied. For example, an arbitration agreement can amount to a voluntary waiver of court proceedings and a tacit, unequivocal, waiver of certain Article 6(1) guarantees. ${ }^{95}$ This principle could be extended to mediation, where a party that voluntarily acquiesces in a mediation which results in a settlement could be perceived as tacitly but unequivocally waiving their Article 6(1) rights. ${ }^{96}$

Second, the waiver must be made in a context where there are sufficient minimum safeguards appropriate to the significance of the right waived. ${ }^{97}$ A waiver of the right of access to court must be accompanied by appropriately high safeguards in light of the importance the ECtHR places on the right of access to court. ${ }^{98}$ While it is unclear what safeguards are sufficient, appropriate representation would appear to constitute a sufficient safeguard in appropriate circumstances, ${ }^{99}$ such that a person who had legal counsel present could be deemed to have waived their right of access to court when they agreed to a mediated settlement agreement. ${ }^{100}$

The third condition is that the right waived must not run counter to any important public interests. ${ }^{101}$ However, provided that parties to a commercial mediation are legally represented and are made aware that the settlement agreement when reduced to writing is final, it is unlikely that a waiver in such circumstances could be considered counter to important public interests.

The final condition is that the waiver must not be tainted by constraint. ${ }^{102}$ In Deweer $v$ Belgium, ${ }^{103}$ a butcher faced the stark choice between a fine or the closure of his business until a hearing would take place to determine whether he was guilty of over-pricing meat. In light of the economic pressures of closure and uncertainty about the timing and length of the trial, he opted to pay the fine, despite having an arguable defence that could have vindicated him. The threat of closure of his business within 48 hours, the loss of income, continuing salary costs and the loss of customers over a period of months constituted constraint according to the ECtHR. The fact that the settlement fine was modest relative

92 Deweer v Belgium (1980) 2 EHRR 429.

93 For a detailed discussion of each criterion, see Shipman (n 85) 476-84.

94 Le Compte, Van Leuven \& De Meyere v Belgium (1983) 5 EHRR 183, para 35. See also Shipman (n 85) 477; Leach (n 85) 172-3.

95 Suovaniemi v Finland (31737/96), Decision 23 February 1999.

96 See Shipman (n 85) 478-9.

97 Poitrimol v France (1994) 18 EHRR 130, para 31. See also Shipman (n 85) 477.

98 Golder v UK (1975) 1 EHRR 524. See also Tsirlis and Kouloumpas v Greece (1996) 21 EHRR CD30, para 98; Giorgiadis v Greece ((1996) 21522/93) Report (31), 47. See also Shipman (n 85) 479.

99 See Suovaniemi v Finland (31737/96), Decision 23 February 1999; and Zu Leiningen v Germany (59624/00) Decision 17 November 2005. See also Shipman (n 85) 480.

100 See Fenwick and Phillipson (n 68) 312. See also Shipman (n 85) 480.

101 Hakansson and Sturesson v Sweden (1991) 13 EHRR 1, para 66. See also Shipman (n 85) 477; Leach (n 85) 172-3. 102 See Deweer v Belgium (1980) 2 EHRR 429.

103 (1980) 2 EHRR 429 
to a potential fine of up to 3000 times higher if found guilty in court contributed to the pressure of the closure. ${ }^{104}$

It has been suggested that the principles established in this case could be applied in a context where a party waives their right of access to court by engaging in mediation that results in a mediated settlement agreement. The court concluded that in circumstances where the possibility of trial caused fear, for example, where refusing a settlement resulted in a trial and the possibility of a more severe sanction, this pressure on its own would not be inconsistent with the right of access to court. ${ }^{105}$ However, in determining whether to refuse to mediate a dispute, when proposed by either a judge or another party, a disputant encounters the additional pressures of judicial encouragement and potential adverse costs. ${ }^{106}$

\section{THE COMPULSION TO ADVISE}

In choosing between mediation and litigation, disputants may face pressure in the form of advice and/or encouragement to mediate from their legal advisors and judges, as both lawyers and judges are in turn often under a degree of pressure to encourage parties to settle. ${ }^{107}$

The changes to the CPR introduced following Lord Woolf's Access to Justice Report 108 illustrate the pressure to encourage the use of mediation with the support of various measures, including costs sanctions for parties who win at trial but who unreasonably refused an offer to mediate a dispute that could have settled. ${ }^{109}$ The culture change desired by Lord Woolf that was reflected in the changes to the CPR has become embedded in the civil justice system in England. This is reflected by the Court of Appeal when stressing that the legal profession in England must take note of the judicial direction contained in Halsey'10 and cannot 'shrug aside'111 reasonable requests to mediate with impunity. The court also stated that it is entitled to take an unreasonable refusal into account, even when it occurs before the start of formal proceedings; see rule 44.3(5)(a) of the Civil Procedure Rules 1998'.112 In light of such judicial comments it has been suggested that all members of the legal profession who conduct litigation should

104 Deweer v Belgium (1980) 2 EHRR 429, para 51(b). For a discussion of this case, see Brenda Tronson, 'Mediation Orders: Do the Arguments against Them Make Sense?’ [2006] 25 Civil Justice Quarterly 412-18, 417. See also Matravers (n 49).

105 Deweer v Belgium (1980) 2 EHRR 429, para 51(b). See also Shipman (n 85) 482-3.

106 For a detailed discussion of various approaches to encourage legal professionals and their clients to undertake mediation, see Shirley Shipman, 'Court Approaches to ADR in the Civil Justice System' [2006] 25 Civil Justice Quarterly 181, 186-94.

107 See ibid 188-90; and Shipman (n 85) 483-4.

108 For a full text of the Civil Procedure Rules and Practice Directions for civil litigation in England, see $<$ www.justice.gov.uk/civil/procrules_fin/index.htm>.

109 CPR 1.1(1) provides that: 'These Rules are a new procedural code with the overriding objective of enabling the court to deal with cases justly.' This was later amended to include 'justly and at proportionate cost' with the added explanation that includes 'enforcing compliance with rules, practice directions and orders'. See Jackson (n 52) 31. The CPR was amended in light of the Jackson report, for an overview of the main changes to the CPR introduced by the Jackson report, see T Allen, 'The Jackson Report Amendments to the CPR: What Do They Do to Encourage Settlement (if Anything)?’ (26 March 2013) $<$ www.cedr.com/articles/?item=The-Jackson-Report-Amendments-to-the-CPR-What-do-they-do-toencourage-settlement-if-anything $>$.

110 [2004] EWCA (Civ) 576.

111 [2005] EWCA Civ 358, Ward LJ at para 43.

112 Rix LJ at para 50. Rule 44.3(5) states that the conduct of the parties includes conduct before, as well as during, the proceedings and in particular the extent to which the parties followed any relevant pre-action protocol. 
now routinely discuss with their clients whether their disputes are suitable for mediation. 113

This approach is also reflected in the Mediation Act 2017. Prior to issuing proceedings on behalf of a client, practising solicitors ${ }^{114}$ and barristers (where a client is directly represented by a barrister) ${ }^{115}$ must advise clients to consider mediation as an alternative to litigation. If the client elects to institute proceedings following the provision of information on mediation services, including details of mediators, information about the advantages and benefits of mediation, and information on confidentiality obligations and the enforceability of mediated settlements, the solicitor must provide a statutory declaration with the application confirming that the obligations to advise on the mediation option to resolve the dispute have been discharged.

In the South-African case, Brownlee v Brownlee, ${ }^{116}$ a costs sanction was imposed as a direct consequence of a failure to mediate on the parties lawyers in a way that has not yet happened in England or Ireland. The lawyers effectively agreed not to advise mediation in a case which the judge believed would have benefited from it, and he consequently limited what they could charge their own clients as a result and made no order between the parties. The approach adopted by the court in Brownlee presents a cautionary tale to the legal profession in countries like Ireland that have adopted a costs sanction as part of the legislative armoury to encourage parties to settle disputes regarding what judges might do if lawyers fail to advise their clients about mediation. ${ }^{117}$ This is something that the English Court of Appeal in Halsey 118 effectively made a professional duty and the Mediation Act $2017^{119}$ made a legal obligation.

113 See Lara Clarke, 'Mediation in the Post-Halsey Era' (Mediation Committee Newsletter, IBA Legal Practice Division August 2005) 19.

114 S 14, Mediation Act 2017.

$115 \mathrm{Ibid}$ s 15. This would be quite rare in practice as most clients would in the first instance be represented by a solicitor.

116 Case no 2008/25274.

117 In the USA, under Oregon statute ORS 20.075, 'the diligence of the parties in pursuing settlement of the dispute' is one of the factors that the court should consider in awarding attorney fees. It has been suggested that commercial contracts could provide that the prevailing party may recover its lawyers' fees only if it made reasonable efforts to use the mediation process provided in the contract to resolve the dispute. However, it would be difficult to determine 'reasonable efforts' in practice, not least because of confidentiality and privilege concerns. See Caroline Harris Crown, ‘Are Mandatory Mediation Clauses Enforceable?' (2010) 29(2 spring) Litigation Journal 3-5, 5.

118 [2004] EWCA (Civ) 576. In McManus v Duffy [2008] GLD 17, a case involving a mediation direction under s 15 of the Civil Liability and Courts Act 2004, Mr Justice Feeney noted that, even though the defendant was unwilling and believed that mediation was unlikely to succeed, this did not mean unwillingness to proceed. He believed the test was whether there were benefits to be gained from mediation as opposed to the likelihood of reaching a settlement. This amounts to a much lower threshold than in Halsey, discussed below, and as such could be construed as going much further in support of mediation. It has been suggested that it is difficult to conceive of a case where mediation will not assist, even where it has little reasonable prospect of success. See G Carey, 'Reasonableness and Mediation: A New Direction?' (2010) 28 Irish Law Times 207. See also Fox (n 32) 24 .

119 Even before the introduction of the Mediation Act 2007, the Irish Solicitors code of conduct made provisions in this regard. Part 2.2 (final para) of A Guide to Good Professional Conduct for Solicitors (3rd edn), provides that 'solicitors should familiarise themselves with . . . mediation and . . . recommend [mediation] . . to clients where appropriate. Initiating . . . mediation . . . is consistent with effective and zealous representation' <www.lawsociety.ie/globalassets/documents/committees/conduct-guide.pdf >. The Irish Law Reform Commission had also recommended that the duty on solicitors to advise their clients in relation to mediation should become a legal obligation. See Law Reform Commission (n 38) $72-7$ <www.lawreform.ie/_fileupload/Reports/r98ADR.pdf>. 
In Halsey ${ }^{120}$ the Court of Appeal dismissed the two appeals against costs awarded in favour of successful claimants who had refused to mediate. Dyson LJ held that the burden was on the unsuccessful party seeking a costs sanction against the successful litigant to show why there should be a departure from the general rule that costs should follow the event, and that such a departure was not justified unless it was shown that the successful party had acted unreasonably in refusing to mediate. The Court of Appeal gave a non-exhaustive checklist of factors that may be relevant to the issue of whether a party unreasonably refused to mediate, as follows: ${ }^{121}$

- the nature of the dispute;

- the merits of the case;

- the extent to which other settlement methods were attempted;

- whether the costs involved in the mediation would have been disproportionately high;

- whether any delay in setting up and attending the mediation would have been prejudicial; and

- whether the mediation had a reasonable prospect of success.

However, the weighting given to each factor by the courts is unclear when determining if a refusal to mediate is unreasonable. CPR 1.4(2)(e) requires the court to encourage disputants to mediate their disputes rather than litigate in appropriate circumstances. As made clear by the Court of Appeal, the stronger the court's encouragement, the greater the likelihood that it will find a party's refusal unreasonable when deciding costs. ${ }^{122}$ Unlike the English courts, Irish courts have not had the opportunity to develop costs jurisprudence in a context where a party unreasonably refuses to mediate. However, consistent with the position in England, the Mediation Act 2017 provides that the court should take into account any unreasonable refusal or failure by a party to the proceedings to consider using mediation, and any unreasonable refusal or failure by a party to the proceedings to attend mediation following an invitation to do so when deciding on costs. ${ }^{123}$ The threat of a costs sanction in this context will no doubt put pressure on parties to mediate rather than litigate, and it is arguable in the appropriate circumstances that this constitutes constraint, with the effect that a disputant's waiver of their Article 6(1) rights could be considered tainted. ${ }^{124}$

Since the Deweer case, the ECtHR has introduced the concept of the margin of appreciation when dealing with Article 6 (1) cases. ${ }^{125}$ It has been suggested that in further developing the doctrine of waiver, the ECtHR should recognise that the threat of adverse costs sanctions amounts to pressure with the effect that any waiver of the right of access

120 [2004] EWCA (Civ) 576.

121 See Kent Dreadon, 'Mediation, English Developments in an International Context' (Mediation Committee Newsletter, IBA Legal Practice Division April 2005) 16. See also the decision in P4 Ltd v Unite Integrated Solutions plc [2006] EWHC TCC 2924, as an example of a subsequent case where the court was careful to apply the Halsey framework to the issues in that case. The 'non-exhaustive' aspect of the list of factors has been criticised as potentially being 'infinite', which is seen as unhelpful to the rule of law which demands clarity and consistency as to what constitutes unreasonable refusal to mediate. See also A K C Koo, 'Unreasonable Refusal to Mediate: The Need for a Principled Approach - PGF II’ (2014) 33(3) Civil Justice Quarterly 261$5,264$.

122 See Halsey [2004] EWCA Civ 576, para 33.

123 S 21, Mediation Act 2017.

124 See Shipman (n 85) 489.

125 See Osman v UK (1998) EHRR 10, para 147. See also Leach (n 85) 242-4. 
to court is tainted by constraint. This would need to be balanced against contentions by state parties that the constraint may be justifiable in appropriate cases, for example, where the measure restricting access pursues a legitimate aim, doesn't impair the essence of the right, and finds the proportionate balance between the public interest and the fundamental right of the individual. ${ }^{126}$ Legitimate aims that the ECtHR has accepted include measures to enable the general or efficient functioning of the civil justice system, such as ensuring the efficient use of court resources, or in a context where the concern is the protection of the interests of others. ${ }^{127}$ Financial constraints that prevent disputing parties from taking or defending claims in court have been a particular concern for the ECtHR. While not a direct financial constraint, the threat of adverse costs may, as discussed, be used to encourage recalcitrant parties to engage in mediation. ${ }^{128}$ These factors should also be borne in mind by the Irish courts when parties who appear before them claim that their right of access to court has been breached under the ECHR Act.

\section{Conclusion}

One of the main contentions against compulsory mediation, as discussed above, is that it actually or potentially obstructs constitutional and ECHR principles relating to the right of access to court. In a context where litigation is stayed pending mediation, some have suggested that it hinders a public hearing 'within a reasonable time'. ${ }^{129}$ However, a stay in such circumstances would not create the kind of delay that could be characterised as an infringement of the right of access to court, which in practice often takes no more than four weeks from initial referral to outcome, based on the experience in England and Wales. ${ }^{130}$

When considering the implications of compulsory mediation as it affects constitutional and ECHR principles relating to the right of access to court, reference may be made to the position of arbitration as one of the available 'alternatives' to the court process to resolve disputes. However, arbitration is well established, having been statutebased for some time, ${ }^{131}$ and can be distinguished from mediation as it is a binding adjudicative process for the 'determination of civil rights and obligations' in a private arbitral forum, where parties have contracted out of their right of access to court. Conversely, mediation is non-adjudicative and could not be regarded as a 'determination'. The neutral third party assists the parties in reaching a resolution and, as noted, they are free to leave the process and pursue their claim in court at any time. Hence, the

126 Ashingdane v UK Series (1985) 7 EHRR 528. See also Shipman (n 85) 491.

127 See Shirley Shipman, 'Compulsory Mediation: The Elephant in the Room' (2011) 30 Civil Justice Quarterly 163-91, 181-2.

128 See Shipman (n 85) 491.

129 For an interesting analysis of the arguments for and against the introduction of compulsory mediation in Australia, and the approach of the courts in imposing compulsory mediation in each state and territory, as well as the federal jurisdiction in Australia, see David Spencer and Michael Brogan, Mediation Law and Practice (Cambridge University Press 2006) 265-311.

130 Tony Allen, Mediation Law and Civil Practice (Bloomsbury Professional 2013) 206-7. According to the Courts Service Annual Report 2016, it can take up to four months depending on the time required for the hearing, from the first return date to the date of full hearing on the Commercial List of the High Court, while Circuit Court waiting times for commercial matters in some parts of Ireland can take up to 18 months. See Courts Service Annual Report 2016 at 75 <www.courts.ie/Courts.ie/library3.nsf/(WebFiles)/ 300A3D2A10D824E88025816800370ED2/\$FILE/Courts\%20Service\%20Annual\%20Report\%202016.pd>.

131 The Arbitration Act 2010 governs domestic and international commercial arbitrations in Ireland. Employment and industrial relations disputes are expressly excluded. It repealed and replaced the pre-existing Arbitration Acts 1954-1998. 
compulsion is to initially engage in the mediation process, not an obligation to reach a 'determination' or a resolution. ${ }^{132}$

As noted above, it has been established for some time that arbitration agreements do not breach constitutional or human rights relating to the right of access to court as parties can waive their rights by agreeing to arbitrate their disputes. ${ }^{133}$ However, the courts will intervene to protect the right of access to court where undue pressure is put on a party to enter into a non-judicial adjudicative process such as arbitration, or where there is no real opportunity for a party to agree to such a term in a contract. ${ }^{134}$

In Deweer, constraint to settle by feeling compelled to waive Article 6 rights was not difficult to discern. In a mediation no party should be constrained to settle because continued participation is voluntary. Mediation has been characterised as symbiotic with litigation, in that mediated settlements are often predicated against the risks of failing to achieve the outcome desired in court, and that engagement in the process, even if such engagement is motivated by a degree of compulsion, should consequently not be viewed as conflicting with constitutional or ECHR Act rights of access to court. Much of the concern seems to centre round confusion about the status of mediation, where some judges in other jurisdictions have viewed mediation as an absolute alternative to litigation, rather than a condition precedent to accessing the court process or alternative adjudicative determination. ${ }^{135}$ There appears to be confusion also between the compulsory requirement to initially engage in the process and the voluntary nature of continued participation. ${ }^{136}$ The Mediation Act 2017 is helpfully very clear on this point, as it provides that the parties participate voluntarily and may withdraw from the process at any time. ${ }^{137}$ Hence commercial mediation operates firmly within the shadow of the law, as parties are free to choose not to settle and return to an adjudicatory process to have their dispute determined by a judge or arbitrator. Similarly, the process is confidential, and nothing said during it can be used against a party in later proceedings. Even unreasonable disengagement is not open to criticism in subsequent litigation. ${ }^{138}$

Halsey established the distinction between encouraging mediation, even in the strongest possible terms, and ordering the parties to do so. The thin line between strong encouragement and compulsion is difficult to draw in practice, and with the threat of sanctions there is a risk that encouragement can look more like coercion. ${ }^{139}$ However,

132 Allen (n 130) 204.

133 Scott v Avery 10 ER 1121 (1856), confirmed in O'Connor v Norwich Union Life and Fire Insurance Society [1894] 2 IR 723. Article 5 of the UN Commission on International Trade Law Model Law, adopted in the Arbitration Act 2010, also provides that 'in matters governed by this Law, no court shall intervene except where so provided in this Law'.

134 Allen (n 130) 204. See also Deweer v Belgium (1980) 2 EHRR 429, discussed below.

135 Allen (n 130) 206.

136 Ibid 79.

137 S 6, Mediation Act 2017.

138 Allen (n 130) 80. As noted above, s 10 of the Mediation Act 2017 contains comprehensive confidentiality provisions, subject to limited exceptions. The CEDR Model Mediation Agreement, used widely for commercial mediation agreements in Ireland, also provides comprehensive confidentiality provisions. Hence statements made during the process are protected from subsequent use in proceedings in the event that the mediation proves unsuccessful. The CEDR Model Mediation Agreement is available at $<$ www.cedr.com/about_us/modeldocs>.

139 See Matravers (n 49). See, for example, Dorcas Quek, 'Mandatory Mediation: An Oxymoron? Explaining the Feasibility of Implementing a Court-mandated Mediation Program' (2010) 11 Cardozo Journal of Conflict Resolution 479; Jackson LJ, 'The Role of Alternative Dispute Resolution in Furthering the Aims of the Civil Litigation Costs Review' (RICS Expert Witness Conference, 8 March 2012); Lord Neuberger MR, 'Educating Future Mediators' (Fourth Civil Mediation Council National Conference, London 11 May 2010); Clarke (n 50). 
as discussed above, it is important not to confuse a degree of compulsion to enter into a process from which settlement may result, a process that parties may exit at any time, with the settlement itself, that will be arrived at only when it is reduced to writing and signed by both parties and, in a commercial context, drafted and reviewed by the party's respective legal teams. In this context the guidelines set out in Halsey ${ }^{140}$ are appropriate for the Irish courts to follow in deciding whether costs sanctions could or should be applied. ${ }^{141}$ This approach also means that the court does not have to explore the subjective intentions of the parties during the process. For a party in a dispute, it is critical that the court in recommending mediation remains mindful of the power to excuse them if they can show that mediation would be unreasonable in the circumstances. This approach is consistent with the legislative framework elucidated in the Mediation Act 2017. ${ }^{142}$

Where a party is reluctant to engage in the process due to fears of unreasonable behaviour by the party on the other side, experience from England suggests that few inherently unreasonable parties restrain their unreasonableness to circumstances where mediation confidentiality restricts judicial access to what transpired at the mediation. ${ }^{143}$ Consequently, there may be sufficient evidence of unreasonable conduct available to a court without the need to intrude into the confidentiality of the mediation. This approach would also provide assistance to parties who have a genuine reason to avoid mediation, for example, where a party needs to have a legal point determined, or where unreasonable behaviour by the other side can be shown, but would otherwise assist in developing a mediation culture for resolving commercial disputes in Ireland.

Lord Phillips remarked that, in light of Dyson LJ's declaration that compulsory mediation would be contrary to a party's Article 6 rights, 'he plainly did not consider that the use of a costs sanction was tantamount to compelling a party to [mediate]'. ${ }^{144}$ His remarks highlight the distinction between encouraging parties to mediate and compelling them to do so. It follows that the more severe the potential sanctions, the closer the courts move towards compulsory mediation. It would seem erroneous that in order to avoid the risk of having to pay costs, a defendant should always be prepared to pay a settlement sum amounting to more than the claim is worth. ${ }^{145}$

Irish courts have the benefit of developed jurisprudence from England, the ECJ and the ECtHR in dealing with concerns that a compulsion to mediate infringes upon constitutional and ECHR Act rights of access to court, including the context where a party is subject to a costs sanction for an unreasonable refusal to mediate. This includes the benefit of learning from the mistakes made in Halsey, where there was a misunderstanding regarding the clear distinction between the compulsion to initially engage in the process, at least in terms of attendance, and the voluntary nature of

140 [2004] EWCA (Civ) 576.

141 This view is also supported by the Law Reform Commission, which considers that in general terms the guidelines set out in Halsey are appropriate in deciding whether costs sanctions could or should be applied, specifically because it means, as noted above, that the court does not then have to explore the subjective intentions of the parties during the process. See Law Reform Commission (n 38) 92. See also McManus v Duffy [2008] GLD 17, discussed above.

142 S 21, Mediation Act 2017.

143 See Tony Allen 'Peering behind the Veil of Mediation Confidentiality: A New Judicial Move in Malmesbury $v$ Strutt and Parker' < www.cedr.com/articles/?item = Peering-behind-the-veil-of-mediation-confidentiality-a-newjudicial-move-in-Malmesbury-v-Strutt-and-Parker>.

144 Matravers (n 49).

145 See, for example, the remarks of Jack J in Hickman v Blake Lapthorn [2006] EWHC 12 (QB). 
continued participation. A balance must be struck by the Irish courts when imposing costs sanctions. Encouragement must be weighty enough to avoid being dismissed as a 'mere bureaucratic hurdle', ${ }^{146}$ but it must not be so strong as to amount to coercion and breach constitutional or ECHR Act rights.

The legislative framework is now in place to foster the growth of commercial mediation in Ireland. It is important when introducing statutory mediation schemes that the legislature is cognisant of ensuring that any compulsory aspect comprises a compulsion to initially engage and that the parties are free to leave the process at any time. In order to ensure that such schemes do not constitute constraint, financial or otherwise, and fall foul of constitutional and ECHR Act rights of access to court, the compulsion to consider commercial mediation should only impose a short delay, providing the space within which informed parties may attempt to settle their dispute with the assistance of a trained mediator. Mediation must be presented as a condition precedent to litigation or arbitration, not as the only means of dispute resolution. Provided such schemes are in the general interest and proportionate, the principal of effective judicial protection will not preclude them.

146 Hazel Genn, Paul Fenn, Marc Mason, Andrew Lane, Nadia Bechai, Lauren Gray and Dev Vencappa, 'Twisting Arms: Court Referred and Court Linked Mediation under Judicial Pressure' (Ministry of Justice of England and Wales Research Series 1/07 2007), iii <www.cnmd.ac.uk/laws/judicialinstitute/files/Twisting_arms_mediation_report_Genn_et_al_1.pdf $>$. 